\title{
gerhard weber
}

$100-23$

Alemania occidental vive una época de pujante actividad, también manifestada en su quehacer arquitectónico.

Entre sus arquitectos-Paul Baumgarten.

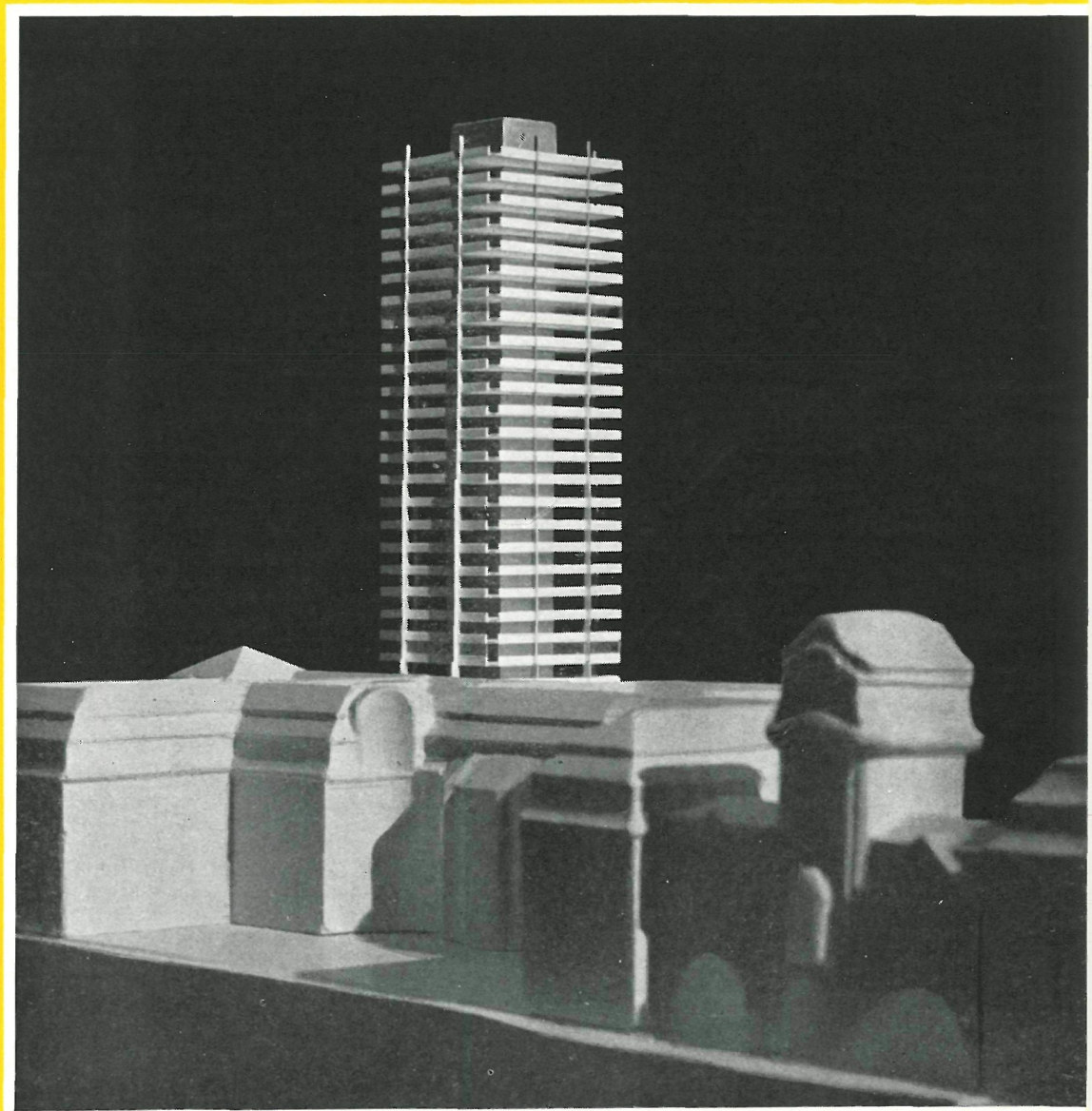

Sobotka, Müller, Neufert...-

destacamos hoy la personalidad de Gerhard Weber,

cuyo prestigio está respaldado

por el número y calidad de sus obras. 
Gerhard Weber nace el 11 de junio de 1909 en Mylau i V.

Cursa sus estudios en Dresde,

Bauhaus, Dessau y Berlín, con Mies van der Rohe

y Hilberseimer.

Trabaja en Alemania y fuera de ella en la construcción industrial

y comercial, y es profesor de la Escuela

Superior Técnica de Munich, desde el año 1955.

Su proyecto preferido es uno presentado a concurso

y no premiado-el edificio administrativo de los Ferrocarriles Federales de Munich-, del que dice: «lo juzgo como uno de mis mejores trabajos de los últimos años». Las fotos de la maqueta ilustran esta editorial.

Entre sus obras podíamos destacar:

La reconstrucción de la Academia de Pedagogía de Frankfurt,

Opera Nacional de Hamburgo, Piscina cubierta en Lübeck,

Laboratorio químico, Instituto de ensayos técnicos

y Edificio administrativo de la empresa August Thyssen-Hütte, así como también las tres obras que hoy ilustran las páginas de Informes:

Edificio de oficinas en Frankfurt,

Teatro nacional en Mannheim y Reactor atómico en Munich.

Fotos: ARTUR PFAU

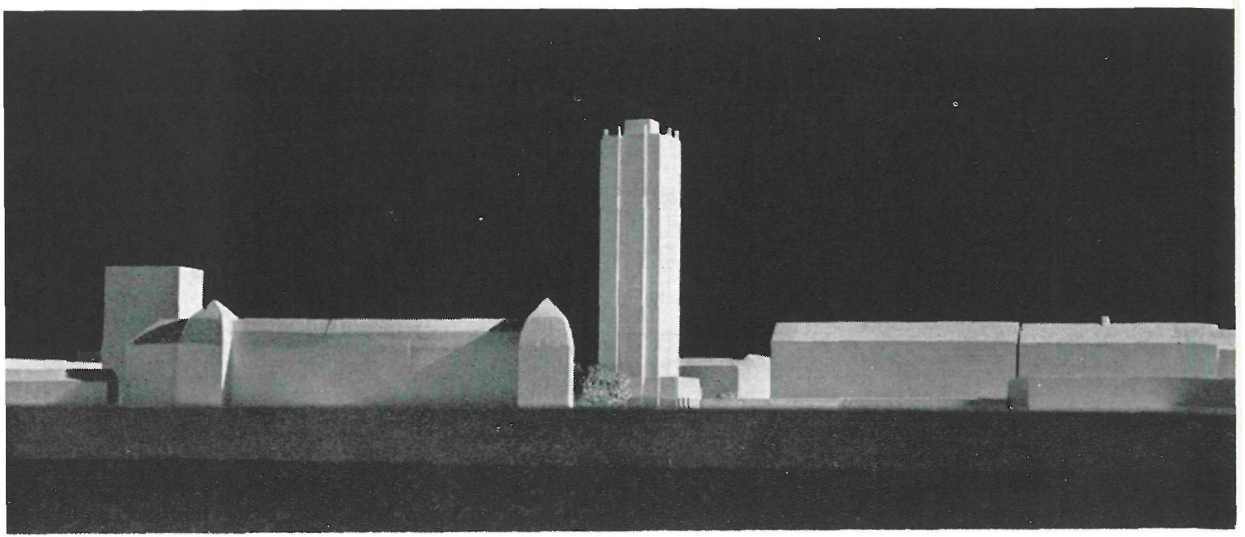

